\title{
The Role of Human Activities in Streambank Stability: Lower Sakarya River (NW Turkey)
}

\author{
Umit Duru* $^{*}$ \\ Geography Department, Sakarya University, Sakarya, Turkey \\ *Corresponding author: umitduru@sakarya.edu.tr
}

\begin{abstract}
The main objective of this study is to determine historic and current human impacts on streambank stability in Lower Sakarya River. Remote sensing and Geographical Information System techniques with conjunction field works were performed to identify the impact of human alteration on streambank stability in the riverine environment of the eastern portion of Sakarya province. LULC (land use/cover) and historical streambank changes were analyzed from Landsat 1-5 Multispectral Scanner (MSS), Landsat-7 Enhanced Thematic Mapper Plus (ETM+), and Google Earth images between 1995 and 2016. As results, a significant LULC changes have been observed along the buffered zone due to population growth. Recently, change in LULC type from agricultural to urban usage has changed river equilibrium. The stream channel also became more stable and straight as man-made modifications including a hydropower (HES) dam constructed in 2010, which primarily reduced flood frequency, water velocity, stream power, shear stress on sediment particles temporarily deposited along the streambank. After the year of 2010, downstream portion of the dam had experienced narrowing and expanding mid-channel bars. Moreover, the channel has been slightly moved towards east especially along urbanized and sinuous courses. The streambank displacement ranged from $2.9 \mathrm{~m}$ to $36 \mathrm{~m}$ in the region. Instream mining activities and bridge constructions in the region also disturb active streambanks, which raise a concern about instability of streambank and potential damage to infrastructures. Such studies are extremely important for understanding basic mechanisms of streambank evolution for further river restoration practices.
\end{abstract}

Keywords: streambank stability, LULC, anthropogenic effects, GIS, Sakarya River

Cite This Article: Umit Duru, "The Role of Human Activities in Streambank Stability: Lower Sakarya River (NW Turkey).” Journal of Geosciences and Geomatics, vol. 5, no. 3 (2017): 130-135. doi: 10.12691/jgg-5-3-4.

\section{Introduction}

Streambank stability is here defined as the resistance of channel bed to natural and anthropogenic changes, and its resilience through years. Besides natural processes, the rate of streambank stability can be greatly altered by human modifications (channel modifications, reservoir constructions, land use/cover changes etc). Although such activities are crucial for development, they may have adverse effects in riverine environment. Human modified the environment to suite their demand and how people adapt to prevail environment is explained by Human environment interactions by the National Council for Geographic Education and the Association of American Geographers. Instream modifications usually lead to a noticeable decrease in bank erosion; channel migration so far as native species conserved in a riparian zone. Human induced changes in a stream channel may culminate in numerous environmental and socioeconomic consequences including loss of riparian zones and damage in infrastructures. For example, concrete armoring channels demolish the species in riparian areas, and removing riparian vegetation can also alter the morphology and natural dynamics of rivers [1,2].
The rivers response anthropogenic activities with several channel parameters for instance incisions, narrowing and migration [3]. These parameters are mainly resulted from disturbing the equilibrium of river dynamics and accelerate the rate of bank erosion. Human induced river bank erosion may become a natural disaster when people destroy natural species and settled within riparian zone, at least $100 \mathrm{~m}$ wide each side. [4] reported that narrower buffers provide habitat benefits for many species; however, protecting various riparian communities requires at least $100 \mathrm{~m}$ buffer zone. Many Geomorphologists have tended to examine the impact of human alterations on riverine environments [5,6,7]. Reference [8] concluded that researchers' knowledge needed to be enriched that how human alters rivers. Numerous other researches have also made significant contribution on alteration of human activities in stream channels such as instream mining operations [9]; dam or bridge contractions [10,11]; channel restorations [12] and LULC (land use/cover) changes [13]. Reference [13] reported that anthropogenic activities have more superior impacts on river dynamics than natural events (Table 1).

Human activities can cause drastic changes to fluvial geomorphic stability of stream channels as a geological agent, respect to leaving some fingerprints on the earth surfaces. In order to examine how human alterations historically impact stream channel, Remote Sensing (RS) 
and Geographical Information System (GIS) techniques have become widely used in the last decades because remotely sensed images provide historical snapshot of stream channel displacements utilizing digital imageries. A reliable monitoring of temporal water resource dynamics using an integrated approach of RS and GIS enable to track historical changes among time intervals [14]. The main objective of the study is to assess how streambanks response LULC changes in the riverine environment of the Sakarya River through years, and discuss potential factors controlling streambank stability in the last decades. Such studies are becoming extremely important for better understanding of current settings, the future and past stream channel evolution, which can be used further stream restoration practices.

\section{Study Area}

The Sakarya River is located in the northwest Anatolian region of Turkey, a length of approximately $820 \mathrm{~km}$ (Figure 1). The basin area of Sakarya River is nearly
$54.000 \mathrm{~km}^{2}$, which is the third largest basin in Turkey. The study area, a length of $8.1 \mathrm{~km}$ and $200 \mathrm{~m}$ wide each side, is situated between D-100 highway to Historical Sakarya Bridge, east of the Sakarya province. The mean annual precipitation in the region is $795 \mathrm{~mm}$, the most of the precipitation falls during Winter $(32,6 \%)$; the lowest precipitation rate seen in the summer (19,7\%) (Figure 2). The region experiences semi-humid characteristics.

The study area lies on alluvial deposits formed late Pliocene - Quaternary with gentle slopes. Cohesionless sand formation is the most dominant in the streambanks, so streambank erosion occurs with lower stream discharge due to lower bed shear stress for sediment transport. The mean annual discharge of $250 \mathrm{~m}^{3} / \mathrm{s}$ is observed at Botbasi gaging station (Figure 3). In the region, 3 ongoing instream mining operations, 2 out of order mining operations, 1 dam construction and 2 bridges leave significant fingerprints riverine environment. Moreover, an ongoing project respecting river restoration (e.g. concrete armoring of streambank, diversions of river) was recently started in the region. The western portions of the Sakarya River have a higher population density (Table 1).
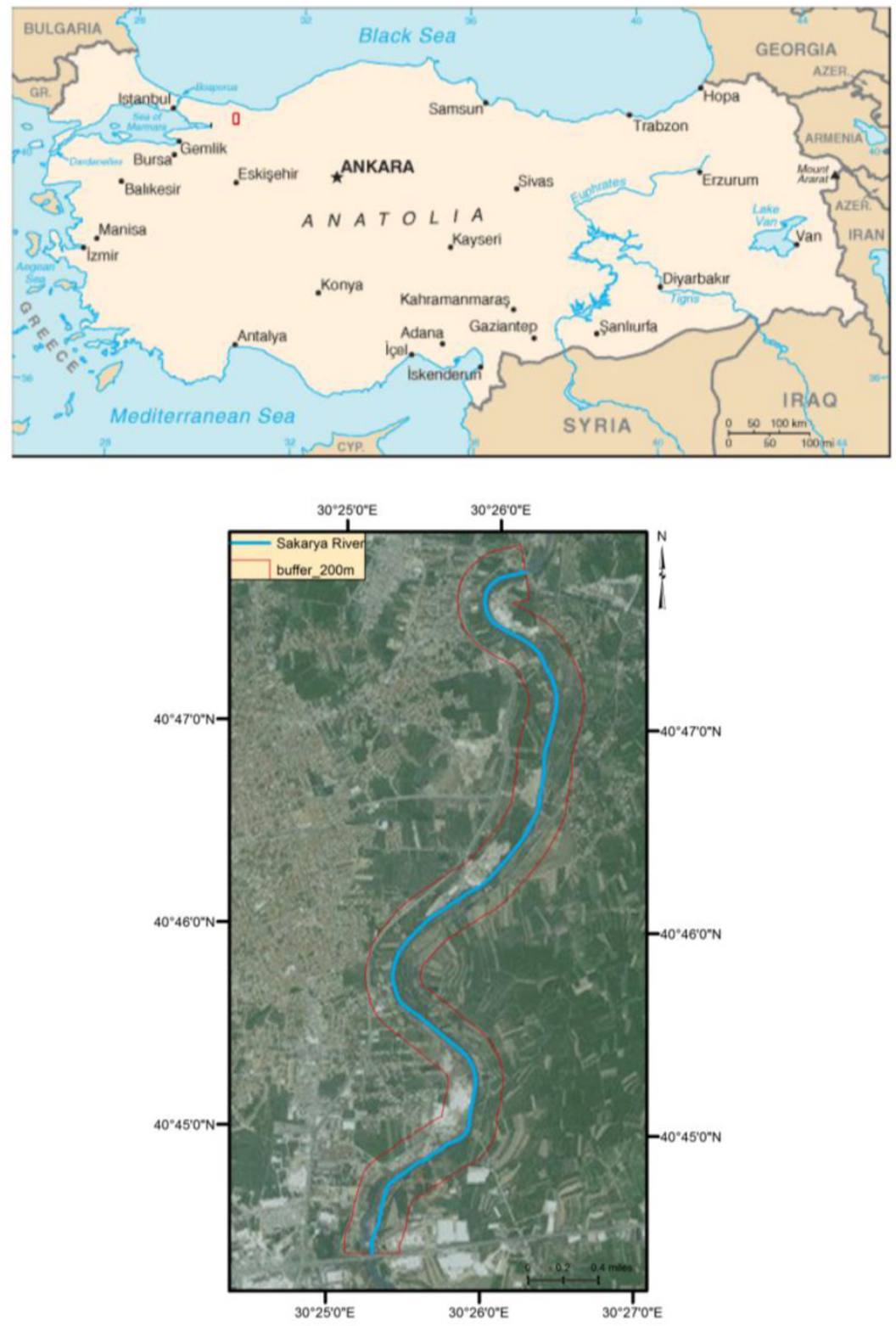

Figure 1. The location map of study area 


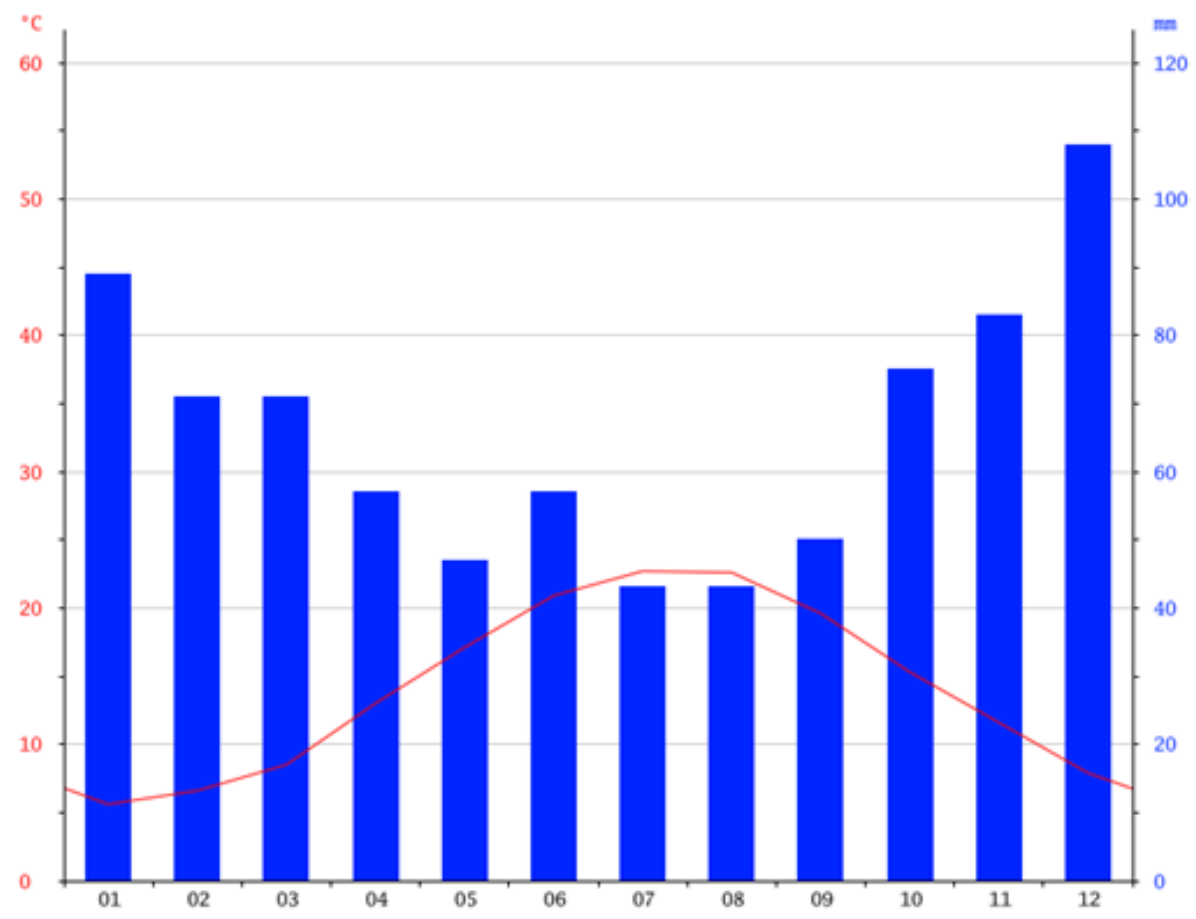

Figure 2. Monthly precipitation and mean temperature at Adapazari Meteorology Station
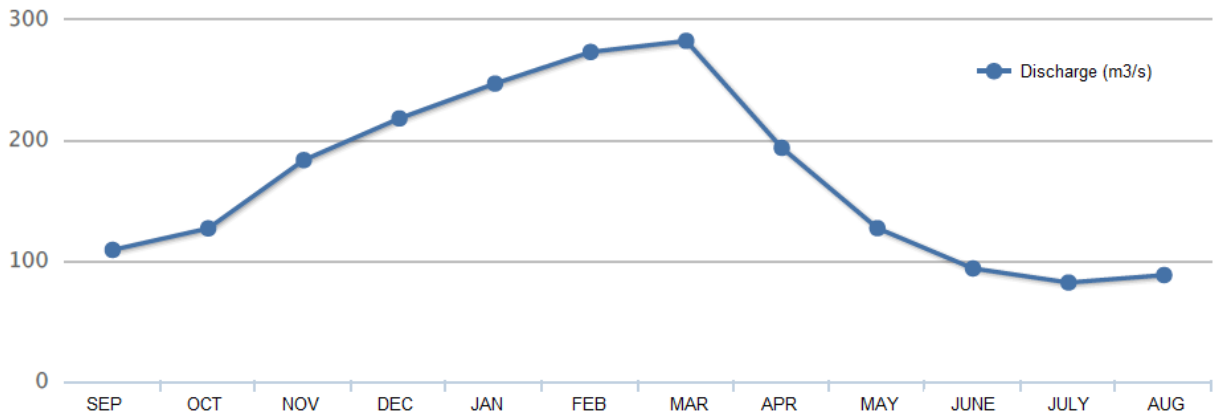

Figure 3. The mean annual discharge is observed at Botbasi gaging station $(1960-2002)$

Table 1. Population of Sakarya (1990-2016)

\begin{tabular}{ccc}
\hline Year & Population & Population Density \\
\hline 1990 & 683.061 & 142 \\
2000 & 756.168 & 156 \\
2010 & 872.873 & 180 \\
2016 & 976.949 & 202 \\
\hline
\end{tabular}

\section{Material and Methods}

Various datasets were used to observe streambank stability in the region. The main input dataset utilized to monitor historical streambank changes are Landsat 1-5 Multispectral Scanner (MSS), Landsat-7 Enhanced Thematic Mapper Plus (ETM+), Aster GDEM, and Historical Google Earth images from 1995 to 2016. All these images in Table 2 provide historical LULC changes along buffered zone of Sakarya River. Water discharge data from 1960 - 2002 at Botbasi gaging station (1243) was collected from State Hydraulic Works of Turkey (DSI). In addition, two field works in 7 January 2017 and 14 March 2017 were conducted to collect data and relevant photographs of the Sakarya River sites where the anthropogenic activities are more pronounced.
Aster GDEM in $30 \mathrm{~m}$ resolution was used to delineate the $200 \mathrm{~m}$ buffer zone along the river. Then the Landsat images were utilized to extract LULC maps. The discrete streambank lines were delineated from the multi-temporal images in ERDAS 9.2 software by using supervised classification, and then all input data were transported into ArcGIS 10.1 software. The comparison of the LULC changes were analyzed from three different images in the three phases 1995 - 2002 (7 years), 2002 - 2016 (14 years), and $1995-2016$ (21 years).

Table 2. Resolution of satellite images utilized in the study

\begin{tabular}{ccc}
\hline Acquisition date & Satellite/sensor & Resolution $(\mathrm{m})$ \\
\hline 9/July/1995 & Landsat MSS & 30 \\
10/May/2002 & Landsat MSS & 30 \\
15/July/2016 & Landsat ETM+ & 30 \\
04/June/2011 & Aster GDEM & 30 \\
2003 - 2016 & Google Earth & 3 \\
\hline
\end{tabular}

\section{Results and Discussion}

Supervised classification method was considered an appropriate method for streambank detection, therefore 
computing the changes in LULC and its effects on streambank stability were assessed in the past 21 years. Two field works were conducted to observe human impacts in riverine environment of the lower Sakarya River. During the field works, boarder of perennial shrubs and trees were examined to define active channel boundary and historical channel migrations because vegetation cannot be excluded in the context of displacement in a streambank. Dam construction, instream mining activities, bank rehabilitations and their effects on streambank stability were assessed in this research.

Environmental concerns have become more important aspect that has been the role of human and its impacts on fluvial systems. Post-settlements changes in LULC have destabilized hydrologic and geomorphologic conditions of these environments. [15] estimated sediment loads were 2.5 times greater than under modern land cover and it may have been five times greater than under pre-settlement forest cover in a Wisconsin watershed during peak agricultural activity in the 1930's. Storm frequency, flow characteristics, bank material composition, bank - channel geometry, moisture conditions and LULC change are necessarily important factors when considering bank erosion [3]. During the past decades, bank erosion rate has been accelerated due to extensive changes of land cover along the Sakarya River.

Prior to establishment of Sakarya HES Dam in 2010, un-regulated peak has been altered further dam constructed upstream course of the region. [16] computed that $20 \%$ of monthly mean flow rate was decreased at Botbasi gauge station due to water withdrawals and diversions from the river and reservoirs. During the past 21 years, because of extensive changes of land use/cover along the lower Sakarya River bank erosion rate has been raised especially at the eastern course of the bank. The stream has been moved towards east more specifically along urbanized and sinuous portions. Correspondingly the displacement of streambanks towards east varied from 2.9 to $36 \mathrm{~m} 1995$ and 2016, respectively.

Adasu hydroelectric power station (HES) was constructed in the year of 2010 (Figure 4a). The power station not only caused a reduction of channel flow, but more importantly flow regimes. The power dam also reduces stream velocity caused decreased in stream power, and the river is transport limited after its operation. After the Adasu HES operation more steady stream characters were observed due to primarily reduced flood frequency, water velocity, stream power, shear stress on sediment particles deposition along the streambank. Fluvial processes cannot be developed at low discharge of water. Despite variation in channel characteristics may occur, the implementation of a dam does not always cause geomorphic changes [3]. After the HES construction even $3 \mathrm{~km}$ downstream portion of the dam had experienced narrowing channel width and expanding mid-channel bars. A reduction in flood magnitude resulting from dam construction has been previously proposed by [17]. Reference [18] reported that flow reduction can promote vegetation establishment in pre-dam channel, which can accelerate the rate of channel narrowing.

After the year of 2010, human impacts especially dam construction and sand mining caused vertical and lateral instability in the streambank. The potential impacts of

instream sand extraction include reduction of water quality and destabilization of the stream bed and banks. Due to lowering stream bank, sand mining has disrupted sediment supply and channel form, which may also result in an incision. Sand extraction operations on point bars along the stream channel have loosened the bank of stream, correspondingly altering channel morphology [19] (Figure 4b, Figure 4d). Channel instability and sedimentation from instream mining can damage public infrastructures. Mining operations are also disrupting riverine flora, because bank erosion, pollute water sources accordingly endanger fauna within riparian zone.

Figure $4 \mathrm{c}$ illustrates disused instream mining places along the outside of the bend. There are numerous pits has captured surface water and create their own environment in the past decades. Out of service instream mining area, 1 $\mathrm{km}$ upstream of the Historic Sakarya Bridge, has recently been used for storing debris removed from the arches of the historical bridge. In fact, surface runoff will eventually transport the stored debris to the stream network, accordingly sediment particles will be temporally deposited at the places later on.

a.
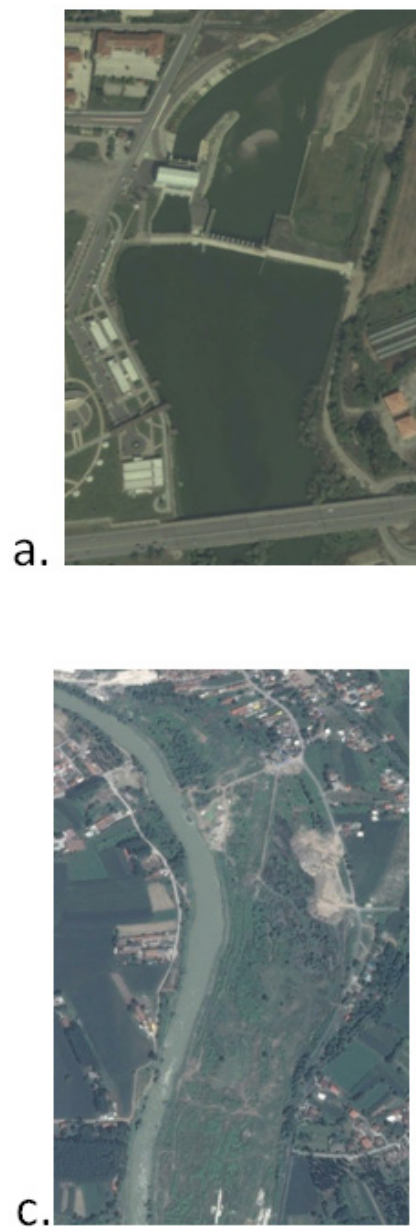

d

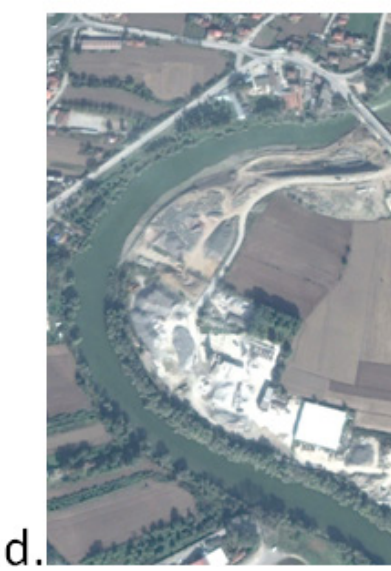

Figure 4. Photograph shows anthropogenic impacts of the study area, (a) Sakarya HES Dam; (b) Instream sand mining operation; (c) Unserviceable instream mining operation; (d) The Historic Sakarya Bridge crossing Sakarya River

Channel incision not only causes vertical instability in the channel bed, but also causes lateral instability in the form of accelerated stream bank erosion and channel widening. Incision increases stream bank heights, resulting in bank failure when the mechanical properties of the bank material 
cannot sustain the material weight. Channel widening causes shallowing of the streambed as deep pools fill with gravel and other sediments. Shallowing and widening of the channel also increases stream temperature extremes, and channel instability increases transport of sediments downstream. Mining-induced bed degradation and other channel changes may not develop for several years until major channel-adjustment flows occur, and adjustments may continue long after extraction has ended.

Additionally bridge contractions caused local scouring as well as sediment accumulation subject to back water effect. Bridge peers reduce velocity of water correspondingly stream power for sediment transport. Recently two arches of the historic bridge were filled with sediment at the downstream course of the study area. From 2003 to 2016, the width of the stream at the Historic Sakarya Bridge has reduced $\sim 20 \mathrm{~m}$, so the stream flows through the bridge using only one arch (Figure 5).
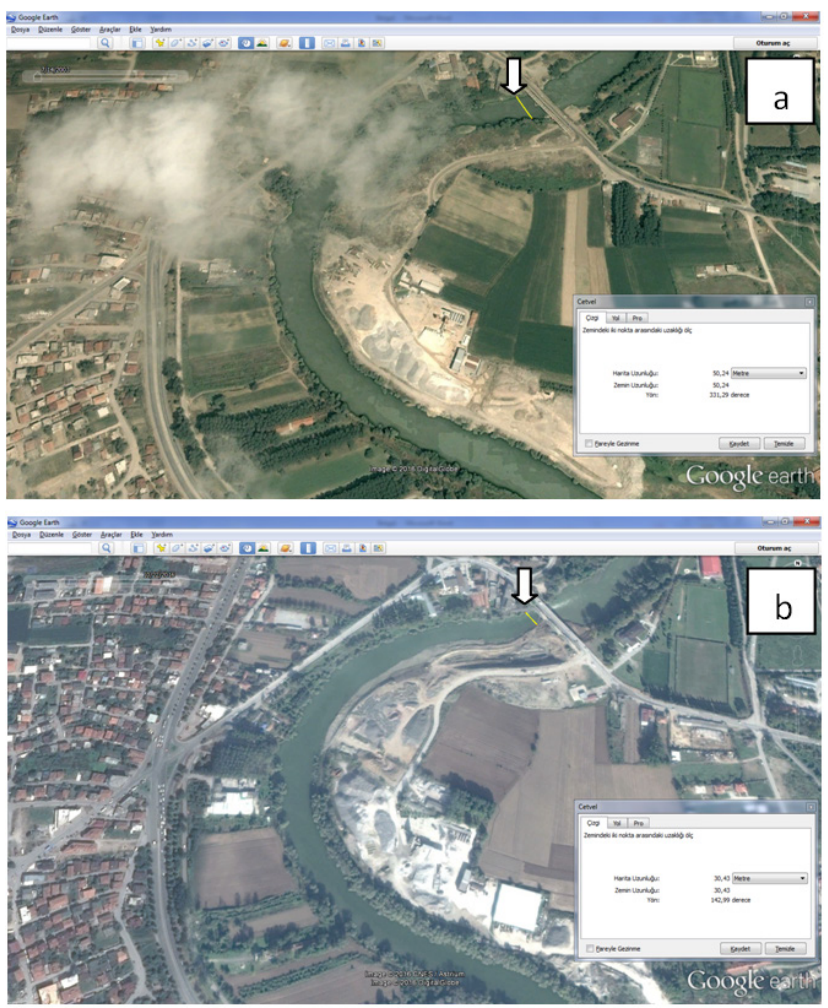

Figure 5. A photograph represents the Sakarya River narrowing process at Historic Sakarya Bridge: (a) Google Earth view in 2003, (b) Google Earth view in 2016

In the last two decades due to extensive changes in LULC along the river, stream bank erosion rate has been increased (Figure 6). Population growth in the research area is significant in the past 2 decades, resulting expanding industrial as well as other anthropogenic activities around the stream channel. Change in land use type from agriculture to industrial usage has disturbed nature of channel dynamics. From satellite images, anthropogenic activities in the buffered zone has been increased as a result of construction infrastructures, settlements and industrial operations, so the channel mainly displaced toward east ranging from 2.9 to $36 \mathrm{~m}$ 1995 and 2016, respectively due to higher amount human activities on the western course of the river. Population growth in the region in the past 21 years is associated with rapid land cover change and as a result expanding settlements, cultivated areas and deforestation in the round of the river. In addition, it should be pointed here that the stream had been narrowed based upon the upstream dam operation and drained water for irrigation. Besides, climate change may also have played a significant role on stream channel narrowing over the past 21 years. Finally forest buffers along the riverine environment had significantly lower soil loss on streambank than streams located in barelands or cultivated lands through years, which can increase stream bank erosion accordingly higher tendency of streambank displacement [20].

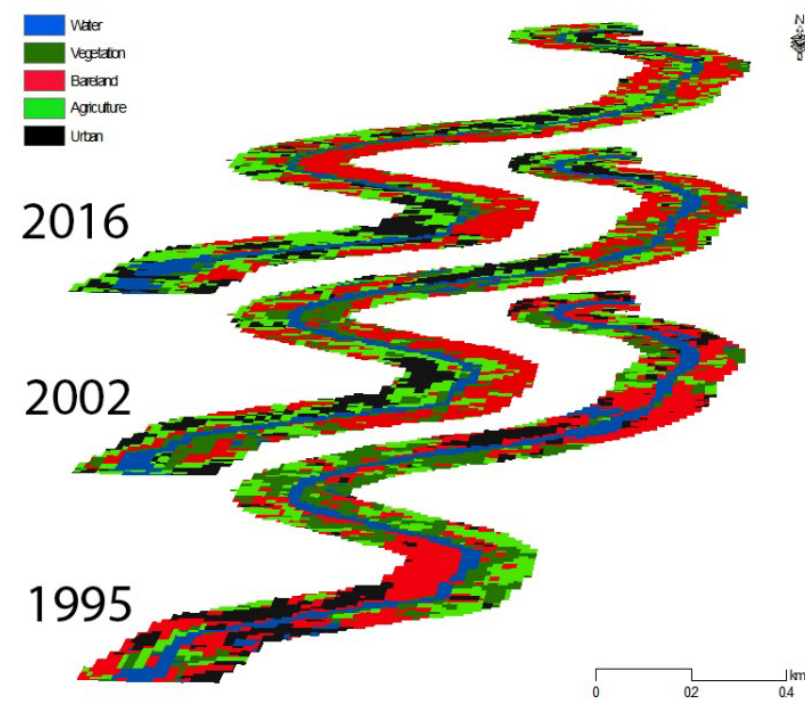

Figure 6. Land use/cover change along Sakarya River (1995 - 2016)

\section{Conclusion}

The anthropogenic activities have an influential role in the Lower Sakarya River. Therefore, bank erosion rate has been accelerated due to extensive changes of land cover along the lower Sakarya River. In the channel, human induced hydrological changes such as dam construction, sand mining and bridge construction have significant impacts on changing streambank stability through years. Although the dam had been constructed for generating electricity, the stream represents steadier stream characteristics. Along urbanized and sinuous portions, the channel has moved towards east. Instream sand extractions have direct impacts on destabilization of the stream bed and banks. Sand extraction in an active channel has a significant impact on streambank mobility.

As a result, population growth in the region in the past 21 years is associated with rapid land cover change and as a result expanding settlements, cultivated areas and deforestation in the round of the river. The results demonstrate that an integrated approach of RS and GIS to monitor anthropogenic impact by overlaying different land cover maps can be a reasonable tool for monitoring streambank stability and channel migration. Such studies need to be supported and taken into consideration before river restorations because better understanding of how streams response to land use changes through years especially for a river flowing through densely populated areas is a significant task for a feasible river restoration practices. 


\section{References}

[1] Kondolf, G.M. (1997). Hungry Water: Effects of Dams and Gravel Mining on River Channels, Profile, Environmental Management, 21(4): 533-551.

[2] Rosso, R., Rulli, M.C. and Bocchiola D. (2007). Transient catchments hydrology after wildfires in a Mediterranean watershed: Runoff, sediment and woody debris, Hydrol. Earth System Sci., 11(1) 125-140.

[3] Knighton, D. (1998). Fluvial Forms \& Processes: A New Perspective. Arnold, New York, 383 pp.

[4] Wenger, S. (1999). A review of the scientific literature on riparian buffer width, extent and vegetation. Athens, GA: Office of Public Service and Outreach, Institute of Ecology, University of Georgia. 59 pp.

[5] Schumm, S.A. (1969). River metamorphosis, J. Hydraul. Div. Am. Soc.Civ. Eng., 1: 255-273.

[6] Goudie, A. (1989). The Nature of the Environment. Basil Blackwell Ltd., Oxford, UK.

[7] Montgomery, M.R. (2008). The urban transformation of the developing world. Science 319:761-764.

[8] James, L.A. and W.A. Marcus (Eds.). (2006). The Human Role in Changing Fluvial Systems. Proc. 37th International Binghamton Geomorphology Symposium, Oct. 20-22, 2006, Columbia, SC. $362 \mathrm{pp}$. The Netherlands: Elsevier.

[9] Ashraf, S., Afshari, H., Ebadi, A.G. (2011). Application of GIS for determination of groundwater quality suitable in crops influenced by irrigation water in the Damghan region of Iran. Int. J. Phy. Sci, $6(4): 843-854$

[10] Gopal, B. (2000). River conservation in the Indian sub-continent In: Boon, P.J., Davies, B.R., Petts, G.E. (Eds.), Global Perspectives on River Conservation. Science, Policy and Practice. Wiley, Chichester, 233-261 pp.

[11] Islam, M.F. and Higano, Y. (2002). Attainment of Economic Benefit through Optimal Sharing of International River Water: A
Case Study of the Teesta River. Indian Journal of Regional Science, 34(2): 1-10.

[12] Schofield, N.J., Collier, K.J., Quinn, J., Sheldon, F., Thoms, M.C. (2000). River conservation in Australia and New Zealand. In: Boon, P.J., Davies, B.R., Petts, G.E. (Eds.), Global Perspectives on River Conservation. Science, Policy and Practice. Wiley, Chichester.

[13] Yamani, M., Goorabi, A. and Dowlati, J. (2011). The Effect of Human Activities on River Bank Stability (Case Study). American Journal of Environmental Sciences, 7(3): 244-247.

[14] Wallick, J.R., Lancaster, S.T., Bolte, J.P. (2006). Determination of bank erodibility for natural and anthropogenic bank materials using a model of lateral migration and observed erosion along the Willamette. River Research and Applications, 2(6): 631-649.

[15] Fitzpatrick, F.A., Knox, J.C. and Whitman, H.E. (1999). Effects of historical land-cover changes on flooding and sedimentation, North Fish Creek, Wisconsin. US Geological Survey Water-Resources Investigations Report 99-4083, 12 pp.

[16] Isik, S., Dogan, E., Kalinsasal, L.M. and Agiralioglu, N. (2008). Effects of anthropogenic activities on the Lower Sakarya River. Catena, 75: 172-181.

[17] Magilligan, F.J., and Nislow, K.H. (2005). Changes in hydrologic regime by dams. Geomorphology, 71: 61-78

[18] Johnson, W.E. (1998). Adjustment of riparian vegetation to river regulation in the Great Plains, USA. Wetlands, 18: 608-18.

[19] Byrnes, M.R. and Hilland, M.W. (1995). Large-scale sediment trans-port patterns on the continental shelf and influence on shoreline response: St. Andrew Sound, Georgia to Nassau Sound, Florida, U.S.A. In: LIST, J.H. and Terwindt, J.H.J. (eds.), Large-Scale Coastal Behavior. Marine Geology, 126: 19-43.

[20] Zaimes, G.N., Schultz, R.C., Isenhart, T.M. (2006). Riparian Land Uses and Precipitation Influences on Stream Bank Erosion in Central Iowa Journal of the American Water Resources Association, 42(1): 83-97. 